UDC 004:34] (477)

DOI: https://doi.org/10.30839/2072-7941.2019.177711

\title{
CONCEPTUAL PARADIGM OF ELECTRONIC UKRAINE FORMING INFORMATION LEGISLATIVE CONTEXT FOR INNOVATIVE DEVELOPMENT OF THE STATE
}

\author{
(C) SOSNIN, OLEKSANDR \\ Academician Member of the Ukrainian Academy of Political Science (Kyiv, Ukraine) \\ E-mail: alvas.sosnin@gmail.com, ORCID iD: 0000-0003-4188-0887
}

Annotation. The relevance of the research is in dynamism and information globalism in all life spheres of a modern post-industrial society, rises to the information one, necessitates multi-dimensional and multidimensional scientific discussions of information, high technologies and innovative breakthroughs in the plane of existing and necessary legal norms in conditions of formation technologies for introducing knowledge and rules for handling information as a resource for the development of modern man, societies and the state. This is actually began in the pre-election program of the President of Ukraine Vladimir Zelensky, which aims to perceive possibilities of modern information and communication technologies (ICT) in the administration of the state and the organization of public and politic life of the country in a qualitative and new way. Purpose of the research is the end-epitualization of the electronic paradigm of Ukraine in the context of the formation of information legislation for the innovative development of the state. Objectives of the research: 1) to identify new problems of information of the state to achieve a more active implementation of innovative ICT in the coordinates of the requirements for creating an e-government system in the country; 2) analysis of the implementation of the state information and communication functions, in a broader sense of the understanding of the concept of "state information policy"; 3 ) analysis of the role of high technology and the scientific and educational sphere in the conditions of the information civilization; 4) identification of the goal of the country's existence in the global world as an electronic state. The research methodology is a systematic and structural-functional analysis of the problem of the electronic paradigm of Ukraine in the context of the formation of information legislation for the innovative development of the state. The scientific novelty of the research is in structuring the problems of the electronic paradigm of Ukraine and finding ways to solve them. Conclusions - the practical implementation of the tasks of the electoral program of the new President of Ukraine V. Zelensky and the tasks of forming the information society in Ukraine raises many questions regarding citizens' access to information accumulated by humanity and the state, and especially in the field of national security and the formation of information legislation.

Key words: presidential election program, e-government, state information policy, information

Problem solving in general and its connection with important scientific or practical tasks

Relevance of research. The dynamism of a modern post-industrial society, which is moving towards informational, necessitates conducting multidimensional multidimensional scientific discussions about information, high technologies and innovative breakthroughs in the area of existing and necessary regulatory norms regarding the conditions for the formation of technologies for introducing knowledge and rules of

Conceptual paradigm of electronic Ukraine forming information legislative context for innovative development of the state 
information handling as a resource for the development of modern man, society and state. This is actually stated in the election program of President of Ukraine Volodymyr Zelensky, who aims to qualitatively and in a new way perceive possibilities of modern information and communication technologies (ICT) in management of the state and the organization of the socio-political life of the country. "Let's face it," appeals to us President of Ukraine V. Zelensky, "Ukraine, which for 28 years was built by the hands of" professional state-makers", today is simply uncompetitive in the world. Modern politics are tied to old images, idolatry, business projects, not able to change Ukraine. Ukraine today needs not just new faces. She needs new ideas! My main task is to bring decent and patriotic specialists to power"[4].

The question arises - what does it mean, what specialists are needed and what qualities they have to answer? It is clear that we are talking about specialists - managers of the new information and communication age, that is, familiar with the technologies of management of society and state affairs, and since the program emphasizes the priority of building the "electronic state", it should be considered all citizens of Ukraine, legal entities and state the authorities have the right to information that provides for the free exercise of such types of information activities as obtaining, using, and disseminating and storing the information necessary for them to realize their $\mathrm{pr}$ in, freedoms and legitimate interests of the tasks and functions.[5]
Purpose of the research is the conceptualization of Ukraine's electronic paradigm in the context of the formation of information legislation for the innovation development of the state.

Objectives of the research: 1) identification of new problems of state information in order to achieve more active introduction of the latest ICT in the coordinates of the requirements for the establishment of e-government system in the country; 2) an analysis of the state's implementation of the information and communication function, in the broader sense of the concept of "state information policy"; 3) analysis of the role of high technologies and the scientific and educational sphere in the conditions of the information age; 4) identification of the purpose of the country's existence in a new global world, as an electronic state.

Methodology of the research systemic and structural-functional, synergetic analysis of the problems of the Ukrainian electronic paradigm in the context of the formation of information legislation for the state's innovation development.

\section{Discussion of the problem.}

Under such conditions, of course, the society faces new and still unknown to the end of the problem in the field of information and communication security of state institutions of power. In the process of fulfilling the information function, since possession of information and means of its distribution and storage everywhere and always actually and gives power. At the same time, the mechanistic picture of the world in the information society becomes crisis- 
related. With the advent of thermodynamics and quantum theory, in the practical sphere, its negative consequences became more and more evident. Anthropocentric picture of the world has led to the fact that nature began to be understood only as a resource and a way of solving human needs. Mathematics reduces cost and quantity to quantity. There was a split in many sciences and only a cybernetic understanding of the world returns us to the appearance of holistic (holistic) thinking.

Thus, it can be assumed that the election program poses the question of improving the quality of management of society's development in a new information and communication era, a deeper research of existing, implemented and promising objects of information relations: information, information resources, systems, processes, technologies etc. China is currently offering it by organizing high-level international cooperation forums. They attract the attention of world leaders as they contribute to the country's development through innovation, intensify international cooperation in such advanced areas as digital economy, artificial intelligence, nanotechnology and quantum computing ... They promote the advancement and development of technologies for using Big Date, cloud computing and arrangement of "smart" or smart-cities.

New President of Ukraine, V. Zelensky, is targeting the country to more actively implement the latest ICTs in the coordinates of the requirements for creating an egovernment system in the country, emphasizes that for Ukraine the third millennium is not an ordinary event; with the help of the newest ICTs, our country must go the course of radical reforms, overcoming all the difficulties and complexity of development. It is clear that he directs us to make more efforts to reach the leading positions in all the main aspects of the life of a society that is being computerized. At the same time, the main goal is rightly seen in the construction of a law-governed state, the creation of a democratic and efficient system of state management of affairs through the improvement of scientific and educational activities, constantly emphasizing that the information and communication function of the state becomes extremely significant, it becomes a pledge of the formation of an innovative and socially oriented economy. . In such conditions, the innovative thinking and education of the bureaucracy, their ability to understand that only mastering the society by high technologies, and not only in the field of information and communication activities, opens us the door to the future, as paramount importance. Under such conditions, the purpose of state information policy is to create national information capacity that meets the trends and the most stringent standards of world scientific and technological progress, and therefore, in our opinion, there should be awareness that information policy of the state is not only media activity, but more complex phenomenon.

The pace evolution of our sociopolitical consciousness regarding its

Conceptual paradigm of electronic Ukraine forming information legislative context for innovative development of the state 
legal dimension is certainly impressive, and in many ways, through the evolution of understanding the concepts of "information" and "information and communication technologies". If before the middle of the twentieth century, the information was understood - the exchange of information between people, man and automatic machine, automatic machine and automatic machine, signal exchange in the plant and animal world, from the organism to the organism, then in 1992, taking a basic legal act in the system of information relations regulation in Ukraine, the Law of Ukraine "On Information" (1992) [6], the information is called documented or publicly disclosed information about events and events occurring in society, the state and the natural environment, on events and phenomena in the field of politics, economics, culture, health care, as well as in social, environmental, international and other spheres (Articles 1, 8). (The Law applies to information relations that arise in all spheres of life of the society and the state in obtaining, using, disseminating and storing information.) Today, this legislative definition of information is outdated. According to UNESCO, information is a universal substance that permeates all spheres of human activity, serves as a guide to knowledge and ideas, an instrument of communication, understanding and cooperation, the adoption of stereotypes of thinking and behavior."

Looking at the experience of industrialization that took place in
Ukraine in the twentieth century, we cannot but say that it stimulated the unprecedented world-wide scientific and educational revolution that has made it successful and widely known in the world. In the process of introducing the latest industrial technologies, the world became increasingly closer to us because of the pace of attracting foreign scientific and technological achievements. All this stimulated the formation and development of domestic scientific and educational and scientific and industrial centers, which in particular quickly turned Ukraine into a leading machine-building and aerospace state, integrated it into a high wave of "informational and communicative energy" of humanity. During the "golden decades", a conditioned engineer and scientist (as well as a skilled worker) really became the main productive and political force in the global plan.

By building an e-state, it needs to be taken into account more and more for the completeness of ideas about their meaning and value, as well as the impact on the work of innovators.

Real economy - that is, factories, power plants, communications and infrastructure, real medicine (that is, one that treats real people from real diseases, and does not promise eternal life in the next ten years), etc. things it requires it. The imbalance of the needs of the real economy with the level and quality of education of engineering and technical workers is the cause of the crisis management - a crisis that can no longer be solved in the current society. Of course, while the "stock of safety" created in the "golden decade" was great - nobody 
addressed the problem, but today, when the infrastructure begins to collapse in front of the eyes, the epidemic covers entire regions, and in stores nobody guarantees the quality of products, came time to understand the situation and transfer money from the "beneficial affairs" of oligarchs and businessmen to vital. The problem is systemic and concerns almost everything - in the sense that it is not feasible under the existing conditions of management, and they need to be strengthened. And, of course, education here is just one aspect.

In the modern vocabulary of foreign words, information is interpreted as one of the most common concepts of science, which means: 1) notice of anything; information that is the object of storage, processing and transmission; 3) in mathematics - a quantitative measurement of uncertainty (entropy), the measurement of the system organization. Now that we are in control of artificial intelligence systems algorithms, but they are becoming more powerful and complex, and so far hiding in massive server farms of supranational corporations, where they handle and analyze gigantic arrays of data, we begin to understand that the language it is about the need for changes in determining the meaning of information, information resources, communication and social interactions - about the urgent need to change the human development management system, as the new President of Ukraine V. Zelensky indicates ..
Under these conditions, we must pay more attention not only to the slogans that generate the policy, but more to the problems of the state's implementation of the information and communication function, in the wider sense of the concept of "state information policy", which should absorb the problems of the development of the national scientific and educational environment, work of libraries, formation of departmental and national web resources, improvement of the quality of the engineering corps ... In our opinion, this, unfortunately, is almost not mentioned in the election program, and without this further development of fur isms effective development of legal regulation of information and communication relations in society, the timely development and adequate justification for action on the innovative development of the country cannot become a priority of state policy. Of course, we must understand and realize that we do not have to wait for the president-elect to come and start something unknown until now, point out some new points of rapprochement, and for future victories we must start to grow the national elite, people to whom any president is forbidden to listen. That is, one must understand that the president does not determine the state's budget, but the elites and intellectuals, whose dedication to the ideas of Ukraine's development is convincing. Under such conditions, the quality of education of our citizens becomes a guarantee that we have such a cohort of people, without which no one president would be able

Conceptual paradigm of electronic Ukraine forming information legislative context for innovative development of the state 
to make a decision. That is, because of the education of young people, in our opinion, we must begin the systematic work announced in the election program of the President of Ukraine V. Zelensky with the aim of identifying and implementing rational means and ways of achieving the goal of innovative development of the country in conditions of almost uncontrolled expansion of the use of ICT in all spheres - from medical to the military.

Perhaps the ignorance by our rulers of such simple, at first glance, things, the inability to think professionally, and led to the destruction of Ukraine, and this is the reason for the crisis of state administration, as well as the super crisis that is approaching humanity and which will bury the existing world order today and the domination of the United States, their liberal values, the "rights" of minorities and other means of sophisticated humanmade wealth.

The first thing we need to pay attention to is to simplify procedures for access to meaningful information in order to create political, economic, cultural and legal conditions that will enhance the quality of the development of the national information and communication space - the most important component of the development of civilization and, at the same time, its security in the conditions of the information revolution and the conduct of hybrid wars against us.

Here, we will have to redefine our life position in many respects; it is possible to realize the necessity of redistribution of vital values, as the determining factor of social differentiation in the information society is the level of knowledge, not ownership.

High technologies and the scientific and educational sphere in the information age really turn into an exceptionally strong factor that actively influences the development of mankind. One can argue about the lawfulness of the use of the term "information revolution", which roaming on our and foreign publications. In fact, we have not spoken in recent decades about the only revolutions - social, technetronic, nuclear, genetic, biological, chemical, etc., thus generating inflation of the original concept, and the fact that new information technologies are tangible and significant contribute to revolutionary transformations into life man and society as a whole can hardly be argued and underestimated, and we still have to, sometimes radically, change the system of government decision-making and the rules of handling of the content, which requires personnel and a new system ma their education and training.

Unfortunately, today we have yet to fully develop the nation-wide strategy of entering the country in the third millennium, and integration into the global information and communication space is quite unsystematic. The blame for this, first of all, is to assume two structures that are being controlled by the President of Ukraine - the National Institute for Strategic Studies and the National Academy of Public Administration. Unfortunately, they have not defined even the priorities and precise perceptions of information as a 
resource of the country's development in the new century, when we are at the stage of transition from homo-Fabersapiens to a person of moral and spiritual, when scientific creativity becomes the force that a person changes even the biosphere. Changes are already noticeable and independently of human will, spontaneously, as a natural process, in full accordance with the teachings of V. Vernadsky about the no-sphere [2, $3]$. He predicted that the transition of the biosphere to the no-sphere will take place in several stages, and after the techno sphere and the energy sphere, we will enter the info sphere, where information and information technologies play a leading role. Inevitability in terms of the factors of avalanche growth of global information arrays and the rapid breakthrough improvement of ICTs from the middle of the twentieth century was long overwhelmed by scientists, because, by virtue of its nature, information penetrates everywhere and is a common property of matter. Even in the beginning of the XX century this was foreseen by well-known philosopher N. A. Berdyaev. He substantiated the emergence of changes in society, which will be associated with the development of technology, highlighting three stages of historical development of mankind: 1) naturalorganic; 2) cultural in its own right; 3 ) technically-machine. About the third stage, he wrote that under the influence of technology changes the very nature of man. It becomes more organized and constructive. This is due to the fact that the technique "destroys the old body and creates new bodies, does not look like organic bodies, creates bodies organized". [1]

In the electoral program of the new President of Ukraine V. Zelensky formulated the goal of the country's existence in a new global world as an electronic state, although it does not outline alternatives and threats against the backdrop of the rather rapid development of telecommunication networks, the Internet, mobile communication, the rapid development of the computer press. , the opening of new sites, the offers of many companies on IT telephony, mobile communications, computers, modems, etc., is very important. Unfortunately, all of these processes occur spontaneously and with an unclear so far a sign for society, with unclear and uncertain consequences in the context of treating unfriendly actions against us by foreign states against us.

For many decades, new ICTs of rapid and even aggressive have spread to the world. They seem to have democratized access to knowledge and unexpectedly enabled the "average person" to receive media and scientific information from around the world, resulting in a new division of labor in the information and communication industry. From this grows even a new, self-confident middle class, free from shackles of state care. He could not have emerged from the former submissive and ignorant mass of Soviet people - and this caused confusion and even a lot of irritation among the creators of the first wave of our independence, who came from bureaucratic offices and

Conceptual paradigm of electronic Ukraine forming information legislative context for innovative development of the state 
defenders of the dogmas of the Soviet era. Their reaction censorship and repression, trying to save their traditional authority by any, most ruthless methods, to take control of technology...

Democracy in its true sense, even in conditions of corruption of administrative structures, involves a high level of organization, strict adherence to the rule of law, and clear mechanisms of state administration. Information only contributes to the rationalization of the actions of the entire state apparatus, the search and selection of the most effective forms and methods of its activities. It more efficiently accumulates knowledge about the world and life of society throughout history and begins to increasingly provide all life processes of society, enriches and harmonizes relations in all areas of life. However, due to the uncertainty of many of its parameters, especially in terms of computer technology and the ability to convey the meaning of the usual definitions by the terms of classical jurisprudence, it is not always possible, as the conceptualization of our actions requires in the resolution of all problems of e-governance, and especially those that arise in particular in processes integration of Ukraine into the global economic and information and communication environment.

The right to information and freedom of information exchange, which declares democracy, on the one hand, are among the fundamental rights and freedoms of citizens, and on the other hand, serve as one of the main mechanisms for the implementation of the right of citizens to participate in the management of public affairs. Sociologists today even offer such a classification of the system of human values: living room life, health, well-being, rest, etc.; social - status, work, family, level of consumption, professionalism, social activity, social equality, law and order, etc.; political - freedom of speech, "the right to know", legality, national sovereignty, guarantees of social justice, etc.; moral - goodness, blessing, love, honor, friendship, debt, etc.; religious - God, faith, salvation, grace, etc.; aesthetic - beauty, harmony, tradition / innovation, imitation of cultural identity, etc. This typology of values in particular is also used in the election program of the President of Ukraine V. Zelensky. Without the proper and necessary quality of the openness of any processes (political, economic, cultural, etc.), their outcome almost always and everywhere, one way or another, most often the most corrupt, is "privatized". At the same time, concrete society and the state in the course of these processes will inevitably acquire, lose, and, as a result, lags in its development from more open (and therefore more efficient) competitors, and therefore the acute problem of our present is not only anti-oligarch policy means mass media (mass media), and in general the entire national economic complex.

Together, these values, due to the requirements of state information openness, are aimed at realizing citizens' rights to information and freedom in the measurement of national, world political, legal and, underline, economic processes. Taken together, they certainly absorb the 
problem of defining the general "right to know" - one of the most significant and fundamental rights that form the global information society of the third millennium or modern electronic civilization.

The right of every people to know and from the standpoint of better knowledge to control their own state became, as already noted, the right of the suffered, a kind of "lesson" with the bitter experience of the inhuman totalitarian state regimes of the 20th century, which brought millions of victims to mankind. The right to know, as well as the right to information, of course, rights is not absolute. They must have (and have!) necessary restrictions, both legal and ethical.

The meaning of the category of "right to know" is the right of the people to know how effectively different branches of public authority, including the judiciary, and "servants of the people", carry out obligations and obligations assumed by themselves in front of their people. Such a politico-legal construct arose originally in the world political and legal doctrine (the phrase "the right to know", was first used by one of the leaders of the "Associated Press" by Kent Cooper in January 1945), and then was enshrined in the norms of international legal norms. Moreover, it was not accidental, but as a reaction to the tragic consequences of a peculiar "illness" of the world community at that time, which can be defined as a certain social immunodeficiency, in turn, is largely due to public information insufficiency. This social "illness" played its fatal role, both during the period of the resolution, and during the Second World War. The lessons of this world massacre have obviously shown that the issues of war and peace have become so socially important in today's world that trusting their discussions and decisions only to politicians, it is now impossible for state structures to do so.

The scientific discussion of the problems of the transformation of the institutions of modern society in connection with the organization of electronic government systems has long been taking place, since they affect literally all aspects of society's life. The waves of the digital age slowly, but steadily, affect the economy, politics, and ethno-social structures, and all the more insistently they form new conditions for the organization of state institutions in order to equip themselves with the lives of their peoples.

Realization of the stated purpose contributes to the rapid development of the digital economy, trade, the creation of "smart" cities, telemedicine ... Today, under the active implementation of ICT, virtually all production processes are digitized, and the emergence of Nano robots and research work on instant teleportation of information suggest that soon the tsunami and meteorites as problems for the existence of mankind will fall into the background or disappear. In a digitized form, information is increasingly coming closer to the properties of the unknown, yet unknown to us, end of a resource-like substance that becomes

Conceptual paradigm of electronic Ukraine forming information legislative context for innovative development of the state 
capable in the hands of a specialist or automatic systems with artificial intelligence to directly influence the effective transformation of material substances in the production processes of a real economy. For this purpose, the human intellect constantly creates more advanced hardware and software for the processing of information, constantly transforming it into a more perfect form that is more suitable for the use of knowledge as a technological component of production processes and can in practice take into account the conditions for the establishment of an innovative climate in the country, the state of the state citizen's sense of justice - views, feelings, ideas and mood. It is the orientation of the digital economy that requires updating the ideas about the state's information policy against the background of the development of the scientific and technical sphere of Ukraine. Further progress in engineering will be impossible without the inclusion of technologies of cloud computing, artificial intelligence, stimulation of international cooperation in the field of communication, energy and transport infrastructure, globalization of production capacities, modernization and optimization of the structure of industry.

China alone has become the second largest digital economy in the world, has made a number of innovations in technologies and models of new technological equipment, and has occupied the leading place in the world in terms of the number of Internet users who need to be monitored daily, to introduce serious methods of obtaining, accumulation and storage of various information that is at the disposal of public authorities, analyzing ways of using it by citizens, since ICTs act as the main means of civilization progress, combining in itself and simultaneously for mankind and colossal good, global threats, and completely new challenges. Inevitably generates more and more new and dangerous forms and species that humanity will still have to find adequate means of countering. From the problems of the destruction of the personal space and those who are experiencing a qualitatively new phase of information and communication enslavement, to the new phenomenon of the twenty-first century - massive cyber-attack and cyber warren. These are completely new forms of conflict that are not properly regulated by existing international law, or by effective mechanisms of international counteraction. The most striking example that focused on the main features of the contradictory sociotechnological and socio-informational processes was the placement on the Wiki Leaks Internet portal of nonpublicized documents and materials on the military actions of coalition states under US leadership in Afghanistan and Iraq: "Afghan Dossier "(July 2010) and" Iraqi Dossier "(23 October 2010). Over time, on the basis of these events, formed, finding visible features and gaining strength, the latest global phenomenon - "the liberalization of the world's information space." From the technological and organizationallegal point of view, it has become a social,

and 
communication phenomenon, which is the application of a special format of electronic social networks designed to maximize (in the given location and time) the disclosure of insider information of national, transnational, government, military or corporate structures by individuals who have decided to publicize certain, still limited access to information.

Information has forced us in many respects to understand and realize the role of the state in a market economy in a new way. From the direct, administrative, management, our state leaves. It became impossible in principle - privatization took away from the state about three quarters of ownership, which it had previously undividedly owned. If before the state was perceived exclusively as an institution of public law, now it becomes a participant in private law relations. However, the modern model of management of the economy affirms with great difficulty. Highlevel information technology is designed to help ensure that the state has a more effective impact on the country's economic development, which should be in line with the fundamental tasks of society, be socially oriented and reflect the balance of interests existing in society.

However, the proposed information should not be interpreted as an incentive for an indispensable strengthening of the state's role in building a real economy. In the regulation of economic processes should be as much as you need, no more, but not less. In any society, including in countries with a developed market economy, the state interferes in the sphere of property turnover, if the interests of the country so require. Incidentally, the strengthening of state influence can, of course, be conditioned by the emergence of a market economy and the control of its state, the realization of the social purpose of the state - its role is played by extraordinary situations, including natural disasters, not to mention the war. Information allows in each case to take accurate, well-balanced and, therefore, most effective decisions. In itself, information is neutral, but it creates favorable conditions for carrying out structural reforms of comprehensive development of market relations, rationalization of business management mechanisms, increase of efficiency of macroeconomic and sectorial, sectorial and territorial systems. New information opportunities facilitate the optimization of the movement of capital, goods and services, adaptation of human reserves in labor markets to changing socio-economic conditions. It is difficult to imagine a successful economy in our time without a welldeveloped system of information networks, their active use at all levels of doing business, both business and consumers. Information has shown and proved its opportunities in the expansion of production, ensuring the growth of the welfare of society, solving the problems of combating unemployment. This fully applies to the state, but to the private sector of the economy.

In the medium term, the creation of a more comprehensive information

Conceptual paradigm of electronic Ukraine forming information legislative context for innovative development of the state 
and telecommunication space of the country as the basis for solving the tasks of socio-economic, political and cultural development of Ukraine and ensuring its national security will surely be fulfilled, starting with the implementation of the election program, and only it is necessary to remember that there are two aspects of the state information and communication policy - technological (regulation of the process of development of components of the information environment) and informative (priorities to whom nonsocial activities of participants in the socio-political process). The state, regulating the actions of the two main components of the state information policy: both socio-political, and technical and technological, should pay more attention to the objective change of its tasks in connection with the management traditions in the XXI century, because in today's world conditions there is a transition to a qualitatively new stage of the innovation economy - the industry 4.0.

Much new and useful information brings into the system of international relations. As noted in the Okinawan Charter of the Global Information Society of 2000, ICT is one of the most important factors influencing the formation of a 21 st century society. The action of this Charter is, above all, an appeal to all, both in the public and private sectors, to bridge the international gap in the field of knowledge of information. A solid foundation of ICT policies and actions can change the way we interact to promote social and economic progress around the world. An effective partnership among participants, including joint political cooperation, is also a key element of the rational development of the information society.

Unfortunately, the new President of Ukraine V. Zelensky, emphasizing the need to form the very "informational-communicative", electronic or smart-society, does not mention as a program of action the development of his complete theoretical concept, which could be compared with the concept of building an information society. Although, to a large extent, it is reflected in the program of building information society in Ukraine, which has the form of the Law of Ukraine "On the main provisions of the development of the information society in Ukraine for 2007-2015" (2007) [7], it is indisputable that an information paradigm of development that gives countries a whole new opportunity to drastically change the pace of development of society, the state and the individual, and, most importantly, the ability to create conditions that can put signs of prohibition on the path to degradation, requires a more sophisticated flight Iko-legal definitions especially in the field of information and communication activities protection. Therefore, actual and important today the problem of accelerated formation of the electronic state cannot occur without the development of information law as a branch of law, fully ordered by all its attributes. Today it is no longer possible to manage the state as in the previous period, say, it does not discuss the problem of protecting the right of citizens not to appear in the 
digital environment and many other risks of information for society, which affect individual freedoms of citizens.

To date, power, politics, administration and justice across the state, its unions in the global dimension has been duplicated with global globalization and, to a large extent, from the globalization of the national information and communication sphere. Under such conditions, the information and communication policy of Ukraine, which is subordinated to the goal of creating an e-state, should become a more multifunctional economic, political and ideological complex and, in its nature, correspond to the main tasks of state administration. The subjects of information and communication policy that are created with the help of information and ICT are controlled to affect the minds and minds of people, their behavior and activities, both in the interests of the state and civil society, and in their own interests, must exist and act exclusively in the coordinates of the requirements of democracy and democracy for the sake of the innovative direction of the development of a real economy and politics.

We are accustomed to perceiving that the field of knowledge and in general work with information from the times of Kiev Rus in Ukraine has always been a priority for the state in defining the natural essence and identity of a person, his orientation to existence of the processes in the world. The whole set of procedures and mechanisms for the creation, distribution, use, access, evaluation, storage and destruction of information has always been and determined the system of values of information and communication relations of man as a citizen, society and state. In their center there was not always a person, and society, more than the state, and as a result, the legislation regulating the whole set of problems of information and communication activities, is formed by us so far fragmentary and exists today as an interdisciplinary and, simultaneously, an international integrated institute in the general structure of national legislation.

Starting the way, the new President of Ukraine V. Zelensky must clearly understand that the development of information and communication relations depends largely on the role of the law in the system of supply sources. It's no secret that today many of the issues of information in Ukraine are solved on the basis of by-laws. And the matter is not only in governmental decisions, but also in departmental instructions, which sometimes replace the law, and in the presence of the law contain a deviation from it. The construction of the foundations of an electronic state must then, in principle, be in line with the provisions of the information law, first of all, the right of access of the person to information. Legislation is intended to place more emphasis on information standards that reflect progress in understanding ICTs in leading world countries.

In implementing their commitments to promote the Information Society, the countries of the former G8 together with the

Conceptual paradigm of electronic Ukraine forming information legislative context for innovative development of the state 
European Commission identified eleven priority projects of international importance and demonstrate the potential of the information society, such as:

1. Global list of information (electronically available multimedia list of information relevant to national and international projects and research related to the development of the information society).

2. Global interaction in the development of broadband networks (the organization of international relations between different high-speed networks).

3. Intercultural education and education (innovative approaches to language learning, especially for students and small business).

4. Electronic libraries (a distributed collection of knowledge of humanity, available to most members of society through networks).

5. Electronic museums and galleries (multimedia collections).

6. Environment and natural resources (electronic information resources related to the environment and natural resources).

7. Global Emergency Management (Global Information Network for Emergency and Risk Management).

8. Global application of ICT in health (telematics technologies in the field of medicine).

9. E-government for direct access (use of new ICTs for administrative activities and electronic interaction between executive authorities, legal entities and citizens).

10. Global market for small and medium-sized businesses (development of an environment for open and free exchange of information and provision of global trade services for the benefit of small and medium-sized businesses).

11. Marine information systems (increasing the competitiveness of all maritime activities at the expense of information and telecommunication technologies).

The Okinawan Charter of the Global Information Society identifies the following main areas of development of normative creativity and economic policy in ICT, such as: stimulating competition and innovation; ensuring economic and financial stability, sound macroeconomic management, contributing to more precise business and consumer planning and the benefits of new ICTs; optimization of global networks; the fight against abuse that undermines the integrity of the network; reduction of the digital divide; investing in people to meet the growing demand for ICT specialists in various sectors of the economy; ensuring global access and participation in this process, increasing the level of availability of power for all citizens.

The Okinawan Charter particularly emphasizes that the strategy for the development of the information society involves the development of human resources, whose capabilities must meet the requirements of the information age. The Charter's members undertake to provide all citizens with the opportunity to learn and acquire ICT skills through education, lifelong learning and training. In this regard, it should be emphasized that the information right is an integral part of all efforts to 
introduce into society knowledge in the field of information.

Describing the activity of Ukraine as an independent state in the development and implementation of state policy and law in the field of information and communication today one should understand that since the proclamation of Ukraine's independence we have already created a significant body of legislative and subordinate normative acts that have already become the basis of legal regulation of public information relations. One can even say that the whole set of legal norms and rules has reached an expressive-critical mass and allows at the scientific level to allocate them as information legislation, and the legal scientific institution in the information right and start on a scientific basis, that is, it is quite critical of the achievements available to us , namely:

- presence of a large number of laws and regulations in the field of information and communication relations, which complicates their search, analysis and agreement for practical use;

absence of legal, clear hierarchical unity of laws, which causes a contradictory interpretation of the use of legal norms in practice;

- availability of various laws and regulations regulating public information relations (the object of which is information), which was adopted at different times (different periods) of development, formation and improvement of our statehood. In our legislation, there is not even thorough terms coordination and in general conceptual apparatus, as a consequence, there are a number of people who lack correct definition with a clear meaning.

There are some other remarks, in particular, regarding the understanding of the structure and structure of the legislation system in the field of information relations and approaches to their formation. In separate laws in the system of legislation included norms that are sufficiently fully reflected in subordinate regulations, which creates in practice their rightful application of certain conflicts of norms, some neglect of constitutional provisions, interpretation of laws in favor of subordinate acts of certain ministries, committees, agencies and organizations.

\section{Conclusion}

Undoubtedly, the practical realization of the tasks of the election program of the new President of Ukraine V. Zelensky and the tasks of forming the information society in Ukraine, of course, puts forward many other issues concerning the quality of ensuring access of citizens to information accumulated by mankind and the state, and especially in the field of national security.

It should be noted that today this process is complicated by the rather high level of legal nihilism of citizens and the low authority of the state and legislative branches of power, which, representing new approaches to the formation of information policy, constantly admit populism in their actions, and therefore the entire set of possibilities of ICT is accompanied by growth in ours cybercrime, an increase in foreign influence on the

Conceptual paradigm of electronic Ukraine forming information legislative context for innovative development of the state 
development of mass media, which manipulate information in order to use uncontrolled social aggression of citizens their advantage.

In this context, the new categorical imperative of the global information society becomes increasingly clear: accelerating the formation of an adequate legal and institutional response to the challenges and needs of real life, which is associated with an increase in the welfare of citizens in the context of the massive introduction of modern ICTs. Surprisingly, for all this time, the authorities created a situation where it was virtually impossible for a businessman to conduct honest business in this area in Ukraine.

The new President of Ukraine V. Zelensky will have to ensure the openness and transparency of many processes of political domination already at the supranational, global level, with the risk of their own security loss of authority, in order to allow national civil society organizations to more effectively control state authorities. However, the authorities, as well, will have to increase the quality of the implementation of the information and communication function of citizens' interaction with the bodies of public institutions and thus increase the quality of new democratic channels of communication with citizens through the use of the latest ICTs, building a complex system of egovernment in the country. Synergetic here will become a universal methodological paradigm, which will stimulate the process of updating, will lead to a holistic vision of nature, man and society and will open everyone for cooperation.

\title{
REFERENCE
}

1. Volodymyr, Zelensky election program (Volodymyr Zelensky candidate to the Ukrainian post of President). [Electronic resource] Access mode: https://gazeta.ua/articles/politics/_bez-durnic-i-populizmu-ekspert-proanalizuvavperedviborchu-programu-zelenskogo/882850

2. Legal dimension of state information policy of Ukraine in the context of global challenges. Monograph. Ed. I. Cresina / Kiev: Institute of State and Law of the. V. Koretsky National Academy of Sciences of Ukraine. - 2018 - p. 282.

3. About information: Law of Ukraine dated 02.10.1992 № 2657-CP / / Bulletin of the Supreme Council of Ukraine. 1992. N. 48. Ed. 651.

4. Basic principles of the development of the information society in Ukraine for 20072015: Law of Ukraine dated 09.01.07, No. 537-V // Information from the Supreme Council of Ukraine. - 2007. - No. 12. P. 511. - Ed. 102.

СОСНIH, О. В. - доктор політичних наук, професор, професор, заслужений діяч науки і техніки України, академік Української академії політичних наук (Київ, Україна)

E-mail: alvas.sosnin@gmail.com, ORCID iD: 0000-0003-4188-0887

\author{
КОНЦЕПТУАЛЬНА ПАРАДИГМА ЕЛЕКТРОННОЇ УКРАЇНИ В \\ КОНТЕКСТІ ФОРМУВАННЯ ІНФОРМАЦЙНОГО ЗАКОНОДАВСТВА \\ ДЛЯ ІННОВАЦЙНОГО РОЗВИТКУ ДЕРЖАВИ
}


Анотація. Актуальність дослідження в тому, що динамізм і глобальність інформатизації у всіх сферах життєдіяльності сучасного постіндустріального суспільства, крокує до інформаційного, обумовлює необхідність проведення багатоаспектних та багатовимірних наукових дискусій про інформатизацію, високих технологіях та інноваційних прориви в площині існуючих і необхідних нормативноправових норм про умови формування технологій впровадження знань і правил поводження 3 інформацією як ресурсом розвитку сучасної людини, товариств i держави. Про це власне і йдеться в передвиборчій програмі Президента України Володимира Зеленського, який ставить за мету якісно і по новому сприйняти можливості сучасних інформаційно-комунікаційних технологій (IКТ) в управлінні державою і організації суспільно-політичного життя країни. Мета дослідження концептуалізація електронної парадигми України в контексті формування інформаційного законодавства для інноваційного розвитку держави. Завдання дослідження: 1) виявлення нових проблем інформатизації держави для досягнення більш активного впровадження інноваційних IКТ в координатах вимог створення системи електронного урядування в країні; 2) аналіз виконання державою інформаційно-комунікаційної функції, в більш широкому сенсі розуміння поняття «державна інформаційна політика»; 3) аналіз ролі високих технологій і науковоосвітньої сфери в умовах інформаційної цивілізації; 4) виявлення мети існування країни в глобальному світі як електронної держави. Методологія дослідження - системний і структурно-функціональний аналіз проблеми електронної парадигми України в контексті формування інформаційного законодавства для інноваційного розвитку держави. Наукова новизна дослідження - в структуруванні проблем електронної парадигми України та знаходженні шляхів їх вирішення. Висновки - практична реалізація завдань передвиборної програми нового Президента України В. Зеленського і завдань формування в Україні інформаційного суспільства висуває багато питань щодо доступу громадян до інформації, накопиченої людством і державою, і особливо в сфері національного безпеки і формування інформаційного законодавства.

Ключові слова: передвиборча програма президента, електронне управління, інформаційна політика держави, інформатизація

СОСНИН, А. В. - доктор политических наук, профессор, Заслуженный деятель науки и техники Украины, академик Украинской академии политических наук (Киев, Украина)

E-mail: alvas.sosnin@gmail.com, ORCID iD: 0000-0003-4188-0887

\section{КОНЦЕПТУАЛЬНАЯ ПАРАДИГМА ЭЛЕКТРОННОЙ УКРАИНЫ В КОНТЕКСТЕ ФОРМИРОВАНИЯ ИНФОРМАЦИОННОГО ЗАКОНОДАТЕЛЬСТВА ДЛЯ ИННОВАЦИОННОГО РАЗВИТИЯ ГОСУДАРСТВА}

Аннотация. Актуальность исследования в тому, что динамизм и глобальность информатизации во всех сферах жизнедеятельности современного постиндустриального общества, шагает к информационному, обусловливает необходимость проведения многоаспектных и многомерных научных дискуссий об информатизации, высоких технологиях и инновационных прорывах в плоскости существующих и необходимых нормативно-правовых норм об условиях формирования технологий внедрения знаний и правил обращения с информацией как ресурсом развития современного человека, общества и государства. Об этом собственно и говорится в предвыборной программе Президента Украины Владимира Зеленского, который ставит целью качественно и по новому воспринять возможности современных

Conceptual paradigm of electronic Ukraine forming information legislative context for innovative development of the state 
информационно-коммуникационных технологий (ИКТ) в управлении государством и организации общественно-политической жизни страны. Цель исследования концептуализация электронной парадигмы Украины в контексте формирования информационного законодательства для инновационного развития государства. Задачи исследования: 1) выявление новых проблем информатизации государства для достижения более активного внедрения инновационных ИКТ в координатах требований создания системы электронного управления в стране; 2) анализ выполнения государством информационно-коммуникационной функции, в более широком смысле понимания понятия «государственная информационная политика»; 3) анализ роли высоких технологий и научно-образовательной сферы в условиях информационной цивилизации; 4) выявление цели существования страны в глобальном мире как электронного государства. Методология исследования - системный и структурнофункциональный анализ проблемы электронной парадигмы Украины в контексте формирования информационного законодательства для инновационного развития государства. Научная новизна исследования - в структурировании проблем электронной парадигмы Украины и нахождении путей их решения. Выводы практическая реализация задач предвыборной программы нового Президента Украины В. Зеленского и задач формирования в Украине информационного общества выдвигает много вопросов относительно доступа граждан к информации, накопленной человечеством и государством, и особенно в сфере национального безопасности и формирования информационного законодательства.

Ключевые слова: предвыборная программа президента, электронное управление, информационная политика государства, информатизация

Стаття рекомендована до публікаџіï

д.філос.н., проф.В.Г.Воронковою (Запоріжсжя, Україна) Надійшла до редколегї: 07.06.2019 p. Прийнята до друку: 17.06.2019 p. 